\title{
S1620202
}

\section{磁気ディスク装量における間隔リングダンパによる ティスクフラッタの低滅に関する研究}

小金沢新治，山本哲輝，谷弘詞，多川則男 ${ }^{* 1}$

\section{Disk Flutter Reduction Using Disk-Spacer Dampers in Hard Disk Drives}

\author{
Shinji KOGANEZAWA ${ }^{* 1}$, Tetsuki Yamamoto ${ }^{* 2}$, Hiroshi Tani ${ }^{* 1}$ and Norio Tagawa ${ }^{{ }^{1}}$ \\ ${ }^{* 1}$ Kansai Univ. Dept. of Mechanical Engineering \\ Yamatecho 3-3-35, Suita, Osaka, 564-8680 Japan
}

\begin{abstract}
Disk-spacer damper (DSD), a new damper structure, which consists of an aluminum disk spacer having grooves embedded with viscoelastic films, has been developed for reducing disk flutter. We investigated the material properties of the viscoelastic film, such as discrete relaxation spectra, and simulated the damping effect using the material properties. We also measured the damping effect of the DSD and confirmed that the DSD reduces the disk flutter amplitude between the $(0,1)$ mode and the $(0,4)$ mode by $20 \%$ to $30 \%$.
\end{abstract}

Key Words : Damping, disk flutter, hard disk drives, relaxation spectrum, viscoelastic material.

\section{1. 緒}

磁気ディスク装置において、ディスクの面外振動（以下ディスクフラッタ）が位置決め誤差に与える影響は大 きく、さらに記録密度を向上させるためにもディスクフラッタの低減は重要な課題である。これまでに、回転デ イスクに対して数百ミクロン程度に平板を近接させたスクイーズ軸受板(1)が、ディスクフラッタ低減策として実 用化されているが、これには消費電力増加という欠点がある。そこで本研究では、消費電力を増加させない方法 として、積層ディスク間の距離を一定に保持するための間隔リングに粘弾性材料を貼り付けた単純な構造を考案 し、これによりディスクフラッタの低減が確認できたので報告する。

\section{2. 間隔リングダンパ}

図 1 に間隔リングダンパの構造を示す。通常のアルミニウム製の間隔リングに溝部を加エし、そこに粘弾性体 を貼り付けた簡単な構造である。ディスクの積層高さ精度を得るために未加工部分を残し、溝部分にのみ粘弾性 材料を貼り付けている。このような構造では、ディスクの固有振動モードが異なると振動の減衰率に違いが生じ る可能性が考えられる。そこで、(a)外側に粘弾性体を貼付した構造、(b)周方向に三分割して粘弾性体を貼付した 構造、(c)周方向に四分割して粘弾性体を貼付した構造の三種類の間隔リングダンパ構造を用意し、それぞれの各 振動モードに対する減衰率を測定した。使用した粘弾性体に関し、本来は実際に磁気ディスク装置に使用されて いる材料を使用したかったが、それらは入手困難であるため、ニチバン(株)製の NW-10S を用いた。これは、両 面テープとして広く市販されている製品であり入手が容易である。

\section{3. 隇衰性能の有限要秦法による解析と实験}

はじめに、NW-10S の粘弾性を把握するため、簡易的なせん断剛性測定ツールを作製し緩和時間スペクトルの

\footnotetext{
${ }^{* 1}$ 正員, 関西大学（广564-8680 大阪府吹田市山手町 3-3-35）

*2 アイシン・エイ・ダブリュ株式会社

E-mail: skoga@kansai-u.ac.jp
}

[No.14-1］日本機械学会 2014 年度年次大会講演論文集 [2014.9.7-10, 東京] 
測定を行った。ANS Y S での FEM 解析に使用することを考慮し、離散的緩和スペクトルとして同定を試みた。 そして、その結果を用いて間隔リングダンパの減衰特性の解析を行った。減衰特性は、ディスクの全周に等間隔 に 24 点の加振点を取り、それらに位相をランダムとして同振幅の正弦波入力を与えたときの周波数応答のゲイン で評価した (図 2)。解析では、どの間隔リングダンパも振動を低減できるが 3VE, 4VE 構造の効果が大きかった。 また、三種類の間隔リングダンパの試作を行い、ディスクフラッタの測定を行った（図 3 )。どの間隔リングダン パも約 20〜30\% 振動を低減できたが、三種類の効果は解析ほどの差は見られず、ほぼ同等であった。

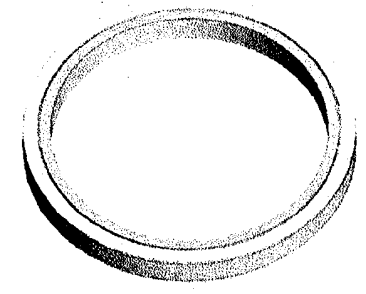

(a) Outer VE

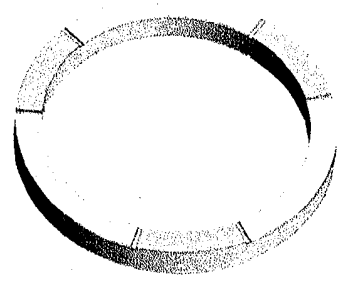

(b) 3VEs

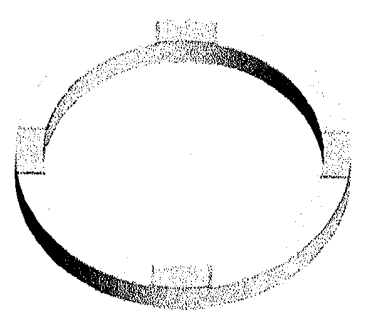

(c) 4VEs

Figure 1 Disk spacer damper structures.

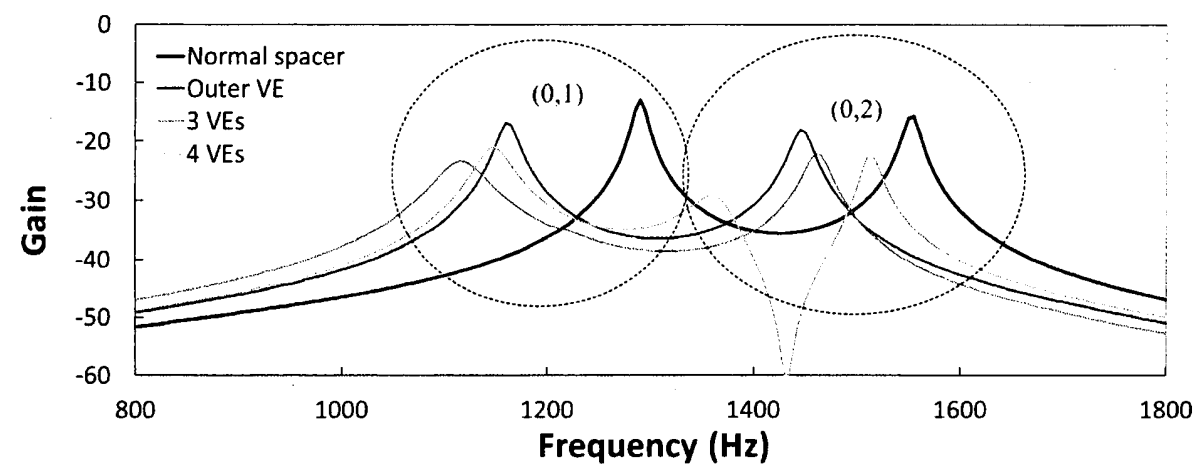

Figure 2 FEM results of frequency response function

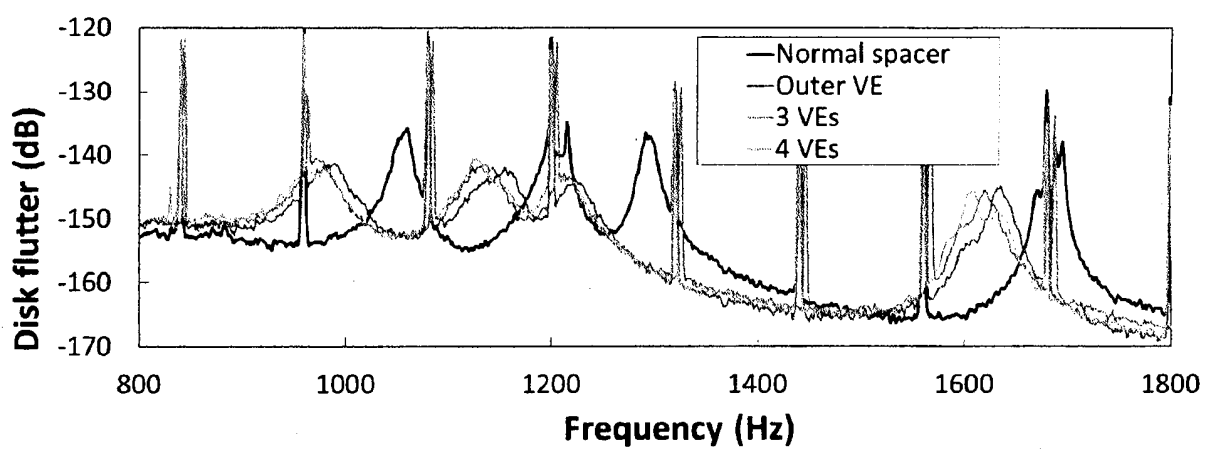

Figure 3 Experimental results of disk flutter power spectra

\section{文献}

(1) K. Ono and E. Maeda, "Suppression of disk flutter by a squeeze air bearing plate," J. Inf. Storage and Process. Syst., vol. 2 , no. $1 / 2,2000$.

(2) Shinji Koganezawa, et. al, "A study on disk flutter reduction using disk-spacer dampers in hard disk drives," Intermag2014 Digest book, HW-16. 